\title{
Pharmacotherapy of peptic ulcer disease
}

\author{
F MOLINA, MD, MM VOHRA, PHD, CN WILliams, MD, FRCPC
}

F MOLINA, MM VOHRA, CN WILlIAMS. Pharmacotherapy of peptic ulcer disease. Can J Gastroenterol 1991;5(1):21-33. The etiology of peptic ulcer is multifactorial; except for omeprazole, all drugs used for the treatment of peptic ulcer result in healing with no statistical difference at four weeks. The healing rate increases with time for active medication and placebo, and is lower among smokers than nonsmokers for all drugs but misoprostol. Mucosal protectives (or 'cytoprotectives') as a group seem to have a lower relapse rate than the $\mathrm{H}_{2}$ receptor antagonists at one year. Combination therapy has not yet proved to be better than single drug therapy; however, the number of studies is still small, and more clinical trials are necessary. Resistant ulcers have demonstrated that acid is one of several etiological factors and that more research is needed to elucidate the reason(s) for refractoriness. The choice of therapeutic agent is generally made according to patient compliance, medication cost, side effects, effectiveness, relapse rate and physician experience with the drug. Long term maintenance therapy is effective in the prevention of ulcer relapse and is especially recommended for selected patient groups, including patients with recurrent or bleeding ulcer, patients with concomitant nonsteroidal anti-inflammatory drug use, and elderly women. Omeprazole is the treatment of choice for moderate to severe esophagitis and should be reserved for large and resistant ulcers.

Key Words: Drug therapy, Duodenal ulcer, Peptic ulcer

\section{Pharmacothérapie de l'ulcère gastro-duodénal}

RESUME: Les causes de l'ulcère gastro-duodénal sont multifactorielles; à l'exception de l'oméprazole, tous les médicaments utilisés dans le traitement de cette affection provoquent la guérison sans aucune différence statistique à quatre semaines. Le taux de guérison augmente avec le temps sous traitement actif et traitement placebo, et il est plus bas pour les fumeurs que pour les non-fumeurs dans le cas de tous les médicaments sauf le misoprostol. Le groupe des cytoprotecteurs semble donner un taux de récidive inférieur à celui des anti- $\mathrm{H}_{2}$ à un an. Le

Departments of Medicine and Pharmacology, Division of Gastroenterology, Dalhousie University, Halifax, Nova Scotia

Correspondence and reprints: Dr CN Williams, Professor and Head, Division of Gastroenterology, Dalhousie University, Halifax, Nova Scotia B3H 4H7. Telephone (902) 494-2333

Received for publication July 17, 1990. Accepted August 20, 1990
$\mathrm{T}$ HE ETIOLOGY OF PEPTIC ULCER DISease is multifactorial $(1,2)$, and factors such as environment, ethnicity, pre-existing disease condition (3), cigarette consumption (4-7) and nonsteroidal anti-inflammatory drugs $(3,8)$ have been implicated. The pathophysiological mechanisms suggest an imbalance between aggressive factors (acid, pepsin and Helicobacter pylori) and defensive factors (mucus, bicarbonate, bloodflow, epithelial cell regeneration, gastric emptying and pyloric function).

The importance of acid in the development of peptic ulcers is supported by the fact that $80 \%$ will heal after four to six weeks of treatment with an acidreducing agent (9). However, maximal acid output in patients with duodenal ulcer overlaps that in normals (3), and basal acid output is not generally increased (3). In contrast, meal-stimulated acid and nocturnal acid secretion are increased in peptic ulcer patients $(3,10)$. The pivotal role of acid in peptic ulcers is further indicated by the fact that these ulcers heal when nocturnal acid secretion is inhibited (10).

Duodenal ulcer patients release more gastrin in response to food than people without ulcers, with less feedback inhibition by luminal acid, and greater parietal cell sensitivity to the secretory effect of gastrin (11). 
traitement par une association médicamenteuse n'a pas encore prouvé sa supériorité par rapport à la monothérapie; cependant, le nombre d'essais est encore bas et il est nécessaire de multiplier les études cliniques. Les ulcères rebelles ont démontré que la sécrétion acide est l'un des nombreux facteurs étiologiques et qu'il faut poursuivre la recherche pour découvrir les raisons de la résistance au traitement. Le choix de l'agent thérapeutique est généralement déterminé en fonction de l'adhésion du patient, du coût du médicament, des effets secondaires, de l'efficacité, du taux de récidive et de l'expérience du médecin avec le médicament prescrit. La thérapie de maintien à long terme est efficace dans la prévention des récidives ulcéreuses et elle est surtout recommandée pour les groupes de patients sélectionnés - les malades porteurs d'ulcères récidivants ou hémorragiques, ceux qui suivent un traitement concomitant d'anti-inflammatoires non stéroïdiens, et les femmes âgées. L'oméprazole est le traitement de choix dans les oesophagites modérées à sévères et il devrait être réservé aux ulcères de grandes dimensions et rebelles.

Without acid, pepsin (to which glycoproteins in gastric mucus, collagen and elastin in the gastric and duodenal mucosa are susceptible) is unable to damage the mucosa, but in combination with acid it produces more severe damage than acid alone $(12,13)$.

The mucus secreted by the surface epithelium of the stomach forms an adherent layer (14) that delays back diffusion of hydrogen ions into the epithelium $(15,16)$, and pepsin diffuses poorly through the mucus (17). However, the amount of mucus secreted is not likely to be enough by itself to maintain a neutral $\mathrm{pH}$ near the epithelial surface when the luminal $\mathrm{pH}$ is 2.0 (18). Stimulated by luminal acid, surface epithelial cells also secrete bicarbonate (19). Although the amount secreted basally is no more than 10 to $15 \%$ of basal acid production (18), and thus is not sufficient to protect the mucosa alone, mucus and bicarbonate together form a barrier that produces a $\mathrm{pH}$ gradient (neutral $\mathrm{pH}$ near the mucosa and an acid $\mathrm{pH}$ in the lumen) $(20,21)$ which prevents mucosal damage from the acid. Another element of defence is a hydrophobic lining of glycolipids over the epithelium, impeding proton diffusion and proteolysis of the mucosa (22).

Mucosal ischemia is the most important factor in acute gastric ulceration (23), because bloodflow is critical in the maintenance of normal mucosal energy stores, aerobic metabolism, buffering and disposal of acid that enters the tissue (24). Hence, gastric blood supply plays an important role in the defence system.

Gastric emptying increases in patients with duodenal ulcer, and the normal response of decreased emptying with acidification of the duodenum is impaired (25). In addition, retrograde duodenal movements are less frequent, less pronounced and less effective, leading to a deficiency in the transport of neutralized duodenal contents and bicarbonate from distal to proximal duodenum, thus lowering $\mathrm{pH}$ in the duodenal bulb (26). Motility abnormalities found in experimental ulcers include decreased waves and mixing waves in the proximal duodenum and increased waves in the distal duodenum (27). Their interaction causes a diversion of biliary and/or pancreatic secretions, with increased incidence and severity of posterior wall ulcer induced by cysteamine in the rat. Correction of this diversion reverses the effect (28).

Recently $H$ pylori has been implicated in the etiology of duodenal ulcer. This microorganism has been found under the gastric mucus layer, adherent to epithelial cells and sometimes concentrated over intracellular junctions (29). H pylori produces a large amount of urease, and the release of ammonia by urease may increase gastric $\mathrm{pH}$, protecting $H$ pylori from gastric acid (30) and undermining gastric mucosal integrity. H pylori was detected in $85 \%$ of 232 patients with duodenal ulcers. It was found in the overlying mucosa of duodenum showing gastric metaplasia, as well as in the gastric mucosa (31). Of
39 patients whose duodenal ulcers healed, $59 \%$ relapsed at one year. The relapse rate was $27 \%$ among patients who were $\mathrm{H}$ pylori culture-negative but $79 \%$ among patients who were $\mathrm{H}$ pylori culture-positive (32). In another group of patients in whom $H$ pylori was eradi. cated, $66 \%$ had a relapse of duodenal ulcer with $H$ pylori recurrence, while only $10 \%$ with no recurrence of $H$ pylori had duodenal ulcer relapse (32).

Antimicrobial agents and bismuth compounds reduce $H$ pylori infection, which is accompanied by healing rates comparable to those obtained with acid suppression, with the added advantage that they may also reduce the relapse rate of duodenal ulcer $(33,34)$. Thus, a combination of tinidazole (an antimicrobial similar to metronidazole) with colloidal bismuth subcitrate healed a greater proportion of patients with duodenal ulcer and eradicated $H$ pylori better than placebo or drug alone. It is likely that the concept of treating duodenal ulcer disease with an antibiotic will be pursued enthusiastically in the near future. The ideal agent, correct dose, duration of therapy for eradication of the organism and rate of recurrence of both organism and ulcer are unknown at this time.

\section{GOALS AND PRINCIPLES OF DRUG THERAPY FOR PEPTIC ULCER}

The goals of therapy are elimination of symptoms, ulcer healing, prevention of recurrence and prevention of complications (35).

The ideal drug for peptic ulcer treatment would: have a $100 \%$ healing rate and no side effects; require only one dose every $24 \mathrm{~h}$; provide antisecretory effectiveness for $24 \mathrm{~h}$; enhance mucosal defence; and benefit the natural history of the disease (36). Unfortunately, no presently available drug fulfills all of these requirements. Patients should avoid the following: foods that provoke symptoms, because although diet chan. ges cannot heal ulcers by themselves, they may alleviate symptoms (37); smoking, because it impairs healing (38); and ulcerogenic medications (39).

The following drugs will be dis. 
cussed: histamine $\mathrm{H}_{2}$ receptor antagonists (cimetidine and related drugs), anticholinergic drugs (pirenzepine), proton pump inhibitors (omeprazole), antacids, sucralfate, bismuth compounds and prostaglandins (misoprostol, enprostil). These agents can be classified according to their sites of action: the parietal cell; the gastric and duodenal lumen; the gastric and duodenal mucosa.

\section{DRUGS THAT ACT ON THE PARIETAL CELL}

Physiological mechanisms of acid production: Gastric parietal cells produce acid in response to three main stimuli: gastrin from $G$ cells in the antral area; acetylcholine from the vagal endings; and histamine from mast-like cells in the fundus area (40). Each of these substances acts on its own receptor site on the parietal cell: muscarinic $M_{1}$ receptors for acetylcholine, histamine $\mathrm{H}_{2}$ receptors for histamine, and gastrin receptors for gastrin. Their actions parallel and facilitate one another ('permissive effect') (41). Receptor activation produces a second messenger (for example, calcium is increased by gastrin and acetylcholine, and cyclic AMP by histamine) with subsequent activation of other cellular processes, leading finally to the activation of the $\mathrm{H}^{+}, \mathrm{K}^{+}$ATPase (the proton pump) and acid production $(42,43)$ (Figure 1 ).

Histamine $\mathrm{H}_{2}$ receptor antagonists: There are now four of these drugs available on the Canadian market: cimetidine, ranitidine, famotidine and nizatidine. All of them act by competitive binding to the $\mathrm{H}_{2}$ receptor.

Cimetidine, the first generation of the histamine $\mathrm{H}_{2}$ receptor antagonists, inhibits acid output in response to all known stimulants of acid secretion, induces prostaglandin synthesis in the gastric mucosa (44), and inhibits the action of gastrin and acetylcholine (45). Reviews of endoscopic studies of the efficacy of cimetidine versus placebo in the healing of duodenal ulcer have found healing rates of 60 to $80 \%$ at four weeks and 85 to $95 \%$ at eight weeks for cimetidine, compared to 35 to $45 \%$ for placebo; this difference was statistically significant $(46-48)$.

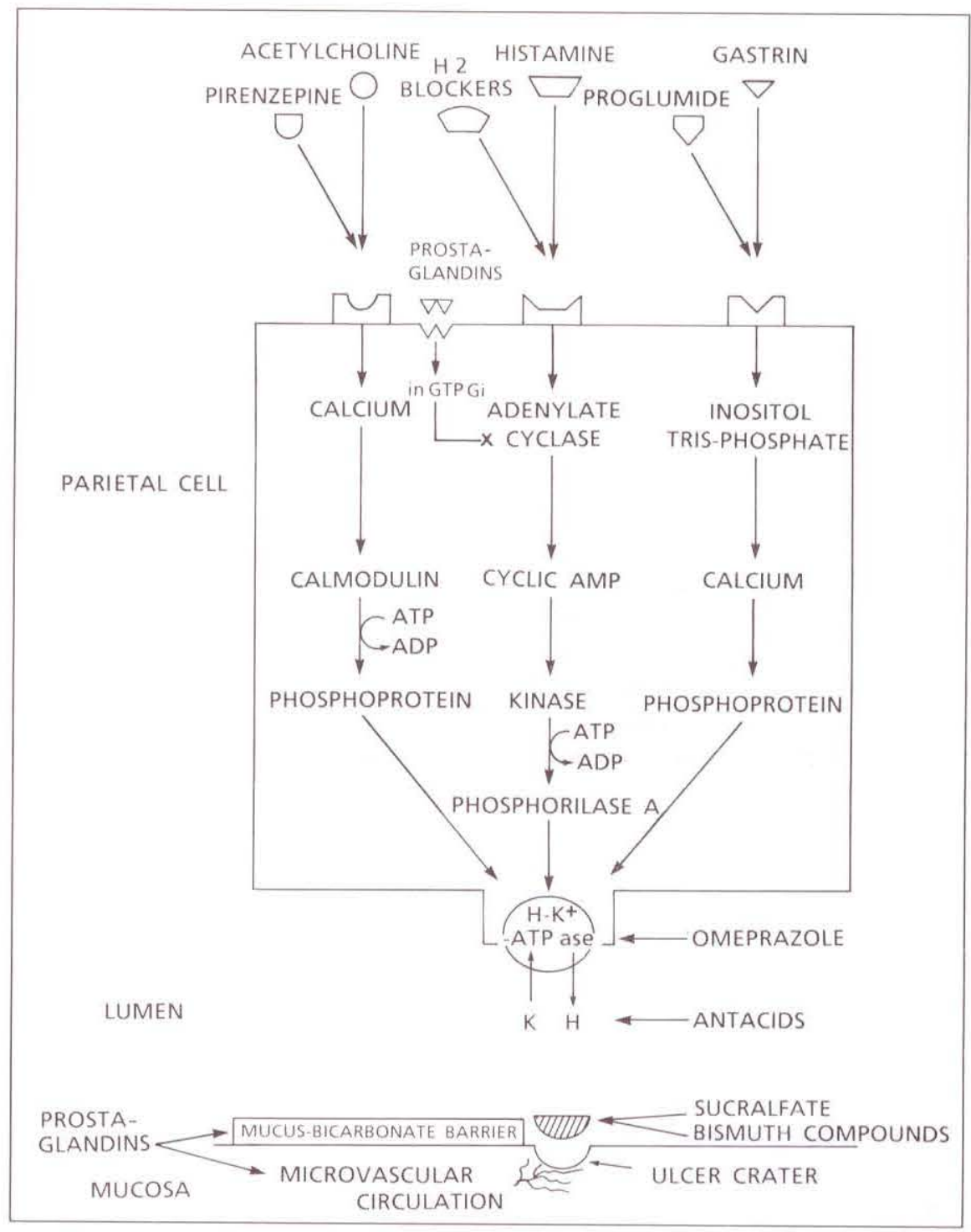

Figure 1) Mechanism of acid production and mechanism of action of different antiulcer drugs. in GTP Gi Inhibitory GTP binding protein Gi; x lnhibits

Originally the recommended dose of cimetidine was $300 \mathrm{mg}$ four times a day, but a dose of $600 \mathrm{mg}$ twice a day was later found to be equally effective in the healing of peptic ulcer (49), and $800 \mathrm{mg}$ at night time has lately proven to be as effective in treating duodenal ulcer as $400 \mathrm{mg}$ twice a day (50). Cimetidine's efficacy is lower among smokers than nonsmokers $(51,52)$, and drug requirement is increased after hemodialysis.

After treatment is discontinued, $80 \%$ of patients healed with cimetidine will relapse in one year (53); however, the relapse rate in the first year is lower among patients receiving cimetidine $400 \mathrm{mg}$ at night for two years than among patients receiving no treatment
(54). Patients who received one year of treatment with cimetidine $200 \mathrm{mg}$ twice a day, $300 \mathrm{mg}$ twice a day or 400 mg at night had a symptomatic recurrence rate of $15 \%$ (versus $35 \%$ among those receiving placebo), and relapse was more common among smokers than nonsmokers (55).

The main side effects of cimetidine include interaction with the hepatic cytochrome P450 system, thus inhibiting the metabolism and thereby increasing the effect of many drugs, especially theophylline, anticoagulants and anticonvulsants (56). Cimetidine produces hyperprolactinemia (57) and may have antiandrogenic effects with male breast tenderness, gynecomastia 
and impotence (58). It may also cause confusion and disorientation in elderly patients and in those with hepatic and renal dysfunction (59). Cholestasis, hepatitis and pancreatitis have also been reported (56).

Most clinically significant adverse effects occur because cimetidine's action is not specific to gastric $\mathrm{H}_{2}$ receptors (60). Thus, cimetidine crosses the blood-brain barrier and binds to some brain receptors $(61,62)$. These side effects occur in a very small percentage of patients under treatment and are reversed when drug administration is stopped.

Ranitidine is a second generation histamine $\mathrm{H}_{2}$ receptor antagonist. It has highly effective, specific competitive binding to $\mathrm{H}_{2}$ receptors in the parietal cell; mole for mole, it is four to five times more potent than cimetidine (63). Although ranitidine has the same pharmacological actions as cimetidine, side effects are much less a problem in patients taking ranitidine $(46,56)$. Ranitidine also interacts with the hepatic cytochrome $\mathrm{P} 450$ system, but because it does so with an affinity about 10 times lower than that of cimetidine, the interaction is of no clinical significance (64). Unlike cimetidine, it does not have antiandrogenic effects (65), does not elevate prolactin levels at therapeutic doses (66), and does not cause mental side effects even though it crosses the blood-brain barrier (56). Hepatitis and transient increases in gammaglutamyltransferase and lactate dehydrogenase have been reported (67).

The healing rate of duodenal ulcer for ranitidine $150 \mathrm{mg}$ bid is 60 to $75 \%$ at four weeks and 85 to $90 \%$ at eight weeks $(46,68,69)$. In other studies, healing rates between 54 and $92 \%$ have been reported at four weeks versus 8 to $46 \%$ for placebo (56). Ranitidine 150 $\mathrm{mg}$ bid is as efficacious as $300 \mathrm{mg}$ at night in healing duodenal ulcer (70). The relapse rate with $150 \mathrm{mg}$ at night is $38 \%$ at one year and $48 \%$ at two years, versus $86 \%$ with placebo (71). Ranitidine's effectiveness in healing ulcers is impaired by smoking (72); comparisons between ranitidine and cimetidine in healing duodenal ulcer in short term treatment have not yielded any statisti- cally significant differences (73). However, ranitidine $150 \mathrm{mg}$ at night was superior to cimetidine $400 \mathrm{mg}$ at night. In long term treatment for prevention of duodenal ulcer relapse, $23 \%$ of patients receiving ranitidine and $37 \%$ receiving cimetidine relapsed (74). In another study the relapse rate was $15 \%$ for ranitidine and $44 \%$ for cimetidine (75). Ranitidine $300 \mathrm{mg}$ at night suppressed nocturnal acid secretion by $85 \%$ and $150 \mathrm{mg}$ bid by $54 \%$ (76), whereas cimetidine $600 \mathrm{mg}$ bid suppressed nocturnal acid secretion by $85 \%$ (77).

Famotidine is a thiazole derivative, different from the imidazole ring of cimetidine and the furan ring of ranitidine. On a molecular basis, it is about 20 times more potent than cimetidine and 7.5 times more potent than ranitidine. Its action can last for $7 \mathrm{~h}$ or more (78). Nocturnal acid secretion is decreased by $80 \%$ with 10 to $20 \mathrm{mg}$ at bedtime. Basal acid and pepsin output are also suppressed (78-81). Famotidine lacks the antiandrogenic activity and drug interactions associated with cimetidine $(81,82)$. Its high potency makes it suitable for treating Zollinger-Ellison syndrome.

Famotidine 20 or $40 \mathrm{mg}$ bid or $40 \mathrm{mg}$ at night produced healing rates at two, four and eight weeks $(83,81$ and $75 \%$, respectively, at four weeks) that were not statistically different from one another or from the healing rate with ranitidine $150 \mathrm{mg}$ bid (83). Side effects diarrhea, anxiety, decreased libido, and mild elevation of bilirubin - were present in a very small percentage of the patients, most frequently in those receiving famotidine $40 \mathrm{mg}$ bid (83). Another study comparing famotidine with ranitidine reported a healing rate of $93 \%$ for ranitidine and $90.2 \%$ for famotidine $40 \mathrm{mg}$ bid, $90.5 \%$ for famotidine $40 \mathrm{mg}$ at night, and $83.3 \%$ for famotidine $20 \mathrm{mg}$ bid; again, the differences were not statistically significant (84). Famotidine $20 \mathrm{mg}$ bid was found to have a healing rate comparable to that of cimetidine $200 \mathrm{mg}$ bid (85). In long term treatment to prevent ulcer recurrence, $32 \%$ of patients taking famotidine $20 \mathrm{mg}$ at night and $63 \%$ of those taking placebo had recurrence at six months of therapy. Constipation was present in $1 \%$ of patients in the famo. tidine group (85). The overall incidence of side effects observed in patients taking famotidine is similar to that observed in patients taking ranitidine; however, more clinical experience is needed to determine famotidine's overall place in the therapy of peptic ulcer disease.

Nizatidine, like ranitidine, contains a furan ring and is a potent, specific and orally well tolerated histamine $\mathrm{H}_{2}$ receptor antagonist. It reduces gastric acid secretion for up to $8 \mathrm{~h}$ and is as potent as ranitidine and three to four times more potent than cimetidine (86). Nizatidine is excreted via the kid. ney, so renal impairment decreases its elimination.

Basal, nocturnal, and food and chemically stimulated gastric acid secretion is inhibited in a dose-dependent manner (87). Unlike cimetidine, nizatidine does not inhibit the microsomal hepatic cytochrome sys. tem, and thus does not inhibit metabo. lism of agents affected by this system, such as theophylline and diazepam (88). It has no antiandrogenic effect and causes less prolactin release than cimetidine (89). Nocturnal acid secretion is decreased up to $90 \%$ with a dose of $300 \mathrm{mg}(90)$.

Nizatidine $150 \mathrm{mg}$ bid and $300 \mathrm{mg}$ at night were equally effective in healing duodenal ulcer at four weeks (67 versus $68 \%$ ), and were superior to placebo ( $29 \%$ of healing rate, $\mathrm{P}<0.02$ ); nonsmokers' ulcers healed more often than did smokers' $(P<0.002)(91)$. In a study comparing nizatidine with ranitidine, the healing rates were 81 versus $80 \%$ at four weeks and 92 versus $93 \%$ at eight weeks, respectively (92).

As maintenance therapy for duodenal ulcer in remission, nizatidine $150 \mathrm{mg}$ at night was superior at one year to placebo (recurrence rates were 34 and $64 \%$, respectively, $\mathrm{P}<0.001$ ) (93). In the prevention of recurrence at six months, nizatidine was comparable in efficacy (relapse rate 18\%) to ranitidine (relapse rate 13\%) (94). Side effects reported on these trials were the same and not statistically different from those reported by patients taking placebo. 
Currently, the histamine $\mathrm{H}_{2}$ receptor antagonists are the cornerstone of prescription peptic ulcer therapy. Effective in healing and preventing relapse of duodenal ulcer, this family of drugs has revolutionized the treatment of peptic ulcer disease by decreasing the likelihood of complications and surgical interventions. Compliance with $\mathrm{H}_{2}$ receptor antagonists is easy: most are available as a once daily dose leading to complete ulcer healing in four to six weeks (although smoking decreases the efficacy of all of them). Because their healing rates and mechanisms of action are similar, the selection of $\mathrm{an}_{2} \mathrm{H}_{2}$ receptor antagonist often depends on 'soft' factors such as previous response to therapy, likelihood of compliance and undesirable side effects. Drug interactions, patient age and the presence of other systemic disease are also important considerations in drug selection, as is cost, since the newer $\mathrm{H}_{2}$ receptor antagonists are much more expensive than cimetidine.

Anticholinergic drugs: Pirenzepine is an anticholinergic drug that has a high affinity for, and inhibits relatively selectively, the muscarinic $M_{1}$ receptor sites located in the parietal cell (95). Thus pirenzepine, which is about one-tenth as potent as atropine, inhibits the acid secretion stimulated by the vagus with a minimum of undesirable cardiac, visual or urinary side effects $(96,97)$. It is a tricyclic pyridobenzodiazepine which structurally resembles the tricyclic antidepressants but, being quite hydrophilic, does not cross the blood-brain barrier and has no central effects (46). Pirenzepine $100 \mathrm{mg}$ reduces nocturnal acid secretion by $41 \%$ (98). Delayed gastric emptying has not been observed with pirenzepine (99). It has a long half-life (11 h), and most of the drug is excreted unchanged in the urine.

In duodenal ulcer treatment, pirenzepine $100 \mathrm{mg}$ has shown superiority over placebo, with a healing rate of 70 to $80 \%$ versus 32 to $57 \%$, respectively, at four weeks (100). Studies comparing pirenzepine with cimetidine (101) and ranitidine (41) showed comparable healing rates. Long term treatment with pirenzepine $100 \mathrm{mg} /$ day to prevent relapse of duodenal ulcer has been shown to be superior to placebo and comparable to cimetidine (102). In a study comparing pirenzepine with placebo, pirenzepine $100 \mathrm{mg} /$ day for one year had a duodenal ulcer relapse rate of $58 \%$, versus $96 \%$ with placebo; this difference was statistically significant (103). Pirenzepine produces side effects at a therapeutic dose of 100 mg (including dry mouth, constipation and urinary delay) in $7 \%$ of patients (104); however, doses lower than 100 $\mathrm{mg} /$ day did not produce as good results as $100 \mathrm{mg}$ in the short term treatment of duodenal ulcers (105). The presence of troublesome side effects when adequate doses are employed indicates a lesser role for this agent, especially when agents without these side effects are now in routine use.

Proton pump inhibitors: Omeprazole, a substituted benzimidazole, is the most powerful inhibitor of gastric acid secretion available. It irreversibly inhibits the $\mathrm{H}^{+}, \mathrm{K}^{+}$ATPase (the proton pump) located in the secretory membrane of the parietal cell, which is the terminal step in the acid secretion pathway. It thus blocks all forms of stimulated and basal acid secretion, producing achlorhydria independently of the nature of the stimulus $(106,107)$. Omeprazole appears to be activated at acidic $\mathrm{pH}$ to a hydrogen ion-activated derivative (a sulphone) which binds irreversibly to the $\mathrm{H}^{+}, \mathrm{K}^{+}$ATPase. This dependence on an acid $\mathrm{pH}$ makes the drug highly selective for actively secreting parietal cells. Also, being a weak base, omeprazole seems to concentrate in the acid environment of the parietal cell (108).

Omeprazole is eliminated rapidly through the liver and kidney, primarily as sulphone, sulphide and hydroxyomeprazole derivatives (mostly the latter). It inhibits reactions mediated by the cytochrome P450 system to the same extent as an equimolar dose of cimetidine; however, as the dose of omeprazole needed for treating duodenal ulcer is 25 to 50 times lower than that of cimetidine, this interaction has little clinical importance, although delays in the elimination of aminopyrine and diazepam have been reported (47). Omeprazole is highly protein bound $(95 \%)$; its plasma halflife is about $1 \mathrm{~h}$; and its pharmacokinetic profile is not altered in chronic renal failure or by hemodialysis. Omeprazole 20 to $40 \mathrm{mg}$ once a day inhibits gastric acid secretion for up to five days, after which time it reaches a plateau (47). A dose of $40 \mathrm{mg}$ decreases acid production by $99 \%$; after the drug has been discontinued for one week, acid production is still inhibited by $26 \%$ $(107,109)$.

Transient side effects include diarrhea, nausea, dry mouth, dizziness, weakness, headache and numbness $(77,110)$. Carcinoid lesions derived from enterochromaffin cell-like have appeared in mature rats after two years on large doses of omeprazole, but this enterochromaffin cell-like hyperplasia seems to be species specific. These tumours are thought to be caused by hypergastrinemia, as high dose ranitidine also causes hypergastrinemia and carcinoid tumours in rats. In addition, prolonged achlorhydria increases gastric bacterial counts, with increased concentrations of nitrates and nitrosamines, which are carcinogenic (108). In another study, these changes were found to return to normal within three days after the drug was stopped (111). Hypergastrinemia also returns to normal after the drug is discontinued (112).

At present omeprazole is only approved for short term treatment in duodenal ulcer disease. Omeprazole 30 mg daily in the treatment of duodenal ulcers had a healing rate of $83 \%$ at two weeks and $98 \%$ at four weeks (113); in another study, $78 \%$ of duodenal ulcers healed at two weeks and $94 \%$ at four weeks, with $30 \mathrm{mg}$ producing better results than $10 \mathrm{mg}$ (109). Compared with cimetidine, omeprazole $30 \mathrm{mg}$ healed $73 \%$ of ulcers at two weeks and $92 \%$ at four weeks; cimetidine $1 \mathrm{~g}$ healed $46 \%$ at two weeks and $74 \%$ at four weeks (114). In a Canadian study, omeprazole $20 \mathrm{mg}$ and cimetidine 600 $\mathrm{mg}$ bid were not statistically different in healing rates at two and four weeks: 58 and $84 \%$ for omeprazole and 46 and $80 \%$ for cimetidine, respectively. There appeared to be a trend in favour of 
omeprazole at two weeks, but not at four weeks (77). Recurrence after discontinuation of treatment is the same as with $\mathrm{H}_{2}$ receptor antagonists (114).

It is likely that omeprazole will be reserved for use in patients with resistant duodenal ulcers and resistant or unusual gastric ulcers (eg, large or multiple ones). Omeprazole is especially useful in Zollinger-Ellison syndrome and will become the drug of choice for moderate to severe cases of peptic esophagitis.

\section{DRUGS THAT ACT IN THE GASTRIC AND DUODENAL LUMEN (ANTACIDS)}

Until 1977, when cimetidine was introduced, antacids were the treatment of choice for duodenal ulcer. Their long term use and clinical trials have now proved their efficacy in this condition. Antacids reduce the acidity of gastric contents by neutralizing hydrochloric acid, and this rise in $\mathrm{pH}$ reduces pepsin activity ( $\mathrm{pH}$ higher than 3.5 to 4 ). In addition, aluminum-containing antacids bind bile. All of these actions decrease damage to the duodenal mucosa and promste healing of the ulcer (104). Antacids can be classified into two groups: those whose reactivity with acid is defined by the anion portion of the molecule (sodium bicarbonate, calcium carbonate) and those in which the cation is more important (magnesium hydroxide, aluminum hydroxide) (115). Dose size and timing should be balanced to promote ulcer healing and avoid side effects. A dose is administered 1 and $3 \mathrm{~h}$ after meals and at bedtime, for a total of seven daily doses.

The buffering capacities of the various antacids vary considerably (6 to 105 $\mathrm{mEq}$ ); it has been suggested that a neutralizing capacity of 200 to $280 \mathrm{mmol}$ is necessary to heal ulcers $(46,116)$. The healing rate using this neutralizing capacity was $85 \%$ at four weeks of treatment in patients with duodenal ulcer (117). In three studies, the healing rates among patients taking antacids with neutralizing capacities of 560 to 1064 mmol for their duodenal ulcers were comparable to those in patients taking cimetidine 800 to $1200 \mathrm{mg}$ (104).

Maalox TC (Rorer) three tablets bid (neutralizing capacity $162 \mathrm{mmol}$ ) prevented ulcer relapse about as effectively as cimetidine $400 \mathrm{mg}$ at bedtime and better than placebo or Maalox TC at bedtime (118). Antacids in liquid suspension have been considered more effective pharmacologically than antacid tablets; however, when the effect of magnesium-aluminum hydroxide antacid tablets or liquid on food-stimulated gastric acidity was evaluated in vivo in eight patients with duodenal ulcer, the duration of effect of tablets was greater than that of liquid suspension (119). Smoking impairs the healing of duodenal ulcer treated with antacids. The relapse rate after treatment is discontinued is the same as when cimetidine is discontinued (120),

The side effects of antacids will depend on the particular antacid in use. Most antacids on the market are mixtures of aluminum hydroxide and magnesium hydroxide, which balance the constipation and diarrhea that the former and the latter, respectively, can cause. Hypernatremia, hypercalcemia, hypermagnesemia, hyperaluminemia, hypophosphatemia, alkalosis, milkalkali syndrome, renal impairment, kidney stones, decreased absorption of fluoride, iron and tetracyclines, and increased absorption of weakly basic drugs (eg, guanidine) have all been reported $(121,122)$. Antacids containing calcium are not recommended in the treatment of duodenal ulcer because they stimulate acid secretion and may thus cause acid rebound $(123,124)$.

\section{DRUGS THAT ACT ON THE GASTRIC AND DUODENAL MUCOSA}

Sucralfate: Sucralfate is a basic aluminum salt of sucrose substituted with eight sulphate groups (125). It is a highly effective, essentially nonsystemic drug for treating peptic ulcer. In the acidic environment of the stomach, aluminum hydroxide dissociates from the sulphate residues in sucrose octasulphonate, leaving it with a negative charge. This reaction is followed by both intra- and intermolecular bridges, producing a variety of polymers and forming a viscous substance (active form) (126). The latter binds preferen- tially to partially denatured or degraded proteins (positively charged) in the ulcer base, forming a protective barrier against back diffusion of hydrogen ions (127). Since the optimal $\mathrm{pH}$ for binding to the ulcer crater is 2 to 3 , sucralfate should be taken when the stomach is empty. Sucralfate also inhibits pepsin activity and adsorbs bile salts (127). It increases prostaglandin synthesis and secretion in the gastric mucosa (128). It is poorly absorbed. Side effects reported are constipation ( 3 to $4 \%$ ), diarrhea, nausea, dry mouth and hypophosphatemia; because of potential aluminum toxicity, its long term use in patients with renal failure should be approached cautiously $(129,130)$. Sucralfate does not interfere with physiological func. tions of the digestive system (acid secretion or motility) (131). Although sucralfate contains aluminum, acid neutralization does not contribute sub. stantially to its therapeutic effect (127).

The healing rate at four weeks in patients with duodenal ulcer treated with sucralfate is 60 to $97 \%$, compared with 24 to $64 \%$ with placebo (129). Compared with cimetidine, the healing rate for sucralfate was similar (132) The relapse rate one year after treatment has been discontinued is $70 \%$ similar to that of cimetidine (133). In a study using a $2.5 \mathrm{~g}$ daily dose of sucralfate maintenance therapy, the relapse rate at one year was $44 \%$ compared with $82 \%$ for placebo (134); another study with $2 \mathrm{~g}$ sucralfate daily showed relapse rate at six months for sucralfate of $21.2 \%$ and for placebo of $50 \%$ (135). Bismuth compounds: Tripotassium dicitrate bismuthate, or colloidal bismuth subcitrate, is a bismuth salt of citric acid. It heals ulcers by binding to proteins and necrotic debris at the ulcer base to form a barrier to the diffusion of acid (136), adsorbing and reducing the concentration and output of pepsin in the stomach for at least $24 \mathrm{~h}$ after the last oral dose (137). In the presence of acid, colloidal bismuth subcitrate yields bismuth oxide and an oxychloride precipitate that forms a tenacious coagulum upon the digestive mucosa. The precipitate acts as a protective layer against erosive chemical attack by acid or pepsin. Also, colloidal bismuth 
has a marked ability to fix chloride ions, with the formation of insoluble bismuth oxychloride, which prevents the diffusion of bismuth ions into the circulation and thus minimizes the systemic toxicity of bismuth. It also stimulates mucus secretion, chelates pepsin and binds bile. Its effectiveness is highly dependent on the $\mathrm{pH}$ of the gastric juice, being greater at low ( 1.0 to 3.5$)$ than at high (3.5 to 6.5) $\mathrm{pH}(41,129,138-140)$. Bismuth compounds colour the tongue and stool black. The liquid preparation has an unpleasant taste and ammoniacal smell. Bismuth compounds are potentially neurotoxic; however, this side effect has never been reported in clinical trials (129).

Healing rates at four weeks of 50 to $89 \%$ (versus 8 to $42 \%$ for placebo) have been reported; all studies showed statistical superiority in favour of bismuth compounds (36,129). Against ranitidine, no statistical difference was found at four and eight weeks of treatment (141). The rates of duodenal ulcer relapse at one year after healing with no maintenance treatment were $39 \%$ with bismuth, $85 \%$ with cimetidine (142, 143), $62 \%$ with bismuth and $89 \%$ with ranitidine (141). These data are statistically significant in favour of bismuth. The lower relapse rate after treatment with bismuth compounds has been related to eradication of $\mathrm{H}$ pylori $(33,34)$. The result was not affected by patient smoking habits (141).

Colloidal bismuth subcitrate is not vet available in Canada except for compassionate use, but it is likely that bismuth subsalicylate, which is available in Canada, is as effective. Bismuth subsalicylate is also the drug of choice for eradication of H pylori. It is the authors' practice to add oral metronidazole 250 mg qid to bismuth subsalicylate $30 \mathrm{~mL}$ gid to increase the likelihood of eradicating $H$ pylori, with rechecking after eight to 12 weeks of therapy. This is particularly relevant for recurrent duodenal ulcer disease and the more controversial symptomatic chronic active antral gastritis.

Prostaglandins: Prostaglandins are a family of biologically related unsaturated fatty acids consisting of 20 carbons and derived from arachidonic acid. They are present in the gastrointestinal tract, especially the stomach, and affect smooth muscle activity and gastric and intestinal secretion. Basal gastric acid secretion and secretion stimulated by food, acetylcholine, gastrin, histamine and insulin hypoglycemia are inhibited by prostaglandins (144). High affinity binding sites for $\mathrm{E}$ type prostaglandins have been identified in canine parietal cells; I and F prostaglandins bind only weakly to this site, and cimetidine and histamine do not bind to it at all. These findings indicate the existence of a particular receptor in the parietal cell for the $\mathrm{E}$ prostaglandins (145). Prostaglandin E2 inhibits histamine-stimulated acid secretion by inhibiting adenylate cyclase via the inhibitory GTP binding protein $\mathrm{Gi}$, which subsequently decreases cyclic AMP production (146).

Prostaglandins have a trophic action on the gastric mucosa, increasing bicarbonate and mucus production in the stomach and duodenum (147-150) and mucosal bloodflow (151). All of these properties have been called 'cytoprotective' (this term has been challenged and some authorities recommend 'mucosal protection', but for the purpose of this review we shall retain 'cytoprotection'). It has been proposed that a deficiency of prostaglandins exists in duodenal ulcer patients. Ahlquist et al (152) found that prostaglandin synthesis in response to acid and food was blunted in duodenal ulcer patients and was markedly higher in normals.

Misoprostol is a synthetic analogue of prostaglandin $E_{1}$ that reduces the volume and concentration of pepsin and acid production in humans (153), decreases gastric acid secretion in response to histamine, pentagastrin and meals in dogs (154) and does not increase gastrin levels (155). Gastrin inhibition by misoprostol is dose-related; its action starts $1 \mathrm{~h}$ after administration and is negligible after 4 to $5 \mathrm{~h}$ (156). While misoprostol has all of the properties of cytoprotection in addition to its antisecretory action, the contribution of cytoprotective activity to misoprostol's clinical efficacy in healing established ulcers is doubtful, since the drug is not superior to placebo when a low antisecretory dose (less than $100 \mu \mathrm{g}$ four times a day) has been used (157). Following oral administration, the drug is rapidly absorbed and de-esterified into its free acid form, which is as potent as the parent compound. Peak concentration is reached in 30 to 60 mins. Misoprostol is about $85 \%$ serum protein bound; it is metabolized in the liver and excreted via the kidney (158).

In a study comparing misoprostol 50 or $200 \mu \mathrm{g}$ qid with placebo in the healing of duodenal ulcer, the ulcers of $42.6 \%$ of patients taking $50 \mu \mathrm{g}$ qid, $51 \%$ taking placebo, and $76.6 \%$ taking 200 $\mu \mathrm{g}$ qid had healed after four weeks of treatment; the higher dose of misoprostol was statistically superior to the lower dose of misoprostol and placebo (159). Another study reported that, after four weeks, the ulcers of $64.9 \%$ of patients taking misoprostol $100 \mu \mathrm{g}$ qid and $47.4 \%$ of patients taking placebo had healed, with significant statistical difference in favour of misoprostol (160). Diarrhea has been the side effect most frequently reported with misoprostol; its frequency is dose-dependent: $4 \%$ with $50 \mu \mathrm{g}$ qid, $8.5 \%$ with $100 \mu \mathrm{g}$ qid and $13.1 \%$ with $200 \mu \mathrm{g}$ qid, against placebo $(5 \%)$. The diarrhea resolves when the drug is discontinued $(159,160)$. Other side effects reported include abdominal cramps, dyspepsia, nausea and headache. Note that misoprostol, like the E prostaglandins, can stimulate uterine contractility and hence is contraindicated during pregnancy or in women at risk of becoming pregnant. Misoprostol $400 \mu \mathrm{g}$ bid has been reported to be as effective as 200 $\mu \mathrm{g}$ qid in the treatment of duodenal ulcer; $200 \mu \mathrm{g}$ bid, however, was no better than placebo (161). After four weeks of treatment, cimetidine $300 \mathrm{mg}$ qid, misoprostol $50 \mu \mathrm{g}$ qid and misoprostol $200 \mu \mathrm{g}$ qid produced healing rates of 67,41 and $60 \%$, respectively. There was no statistically significant difference between misoprostol $200 \mu \mathrm{g}$ and cimetidine; both drugs were superior to misoprostol $50 \mu \mathrm{g}$ qid (162). Cigarette smoking does not impair the healing action of misoprostol in duodenal ulcers (163). Studies are not yet available concerning the use of 


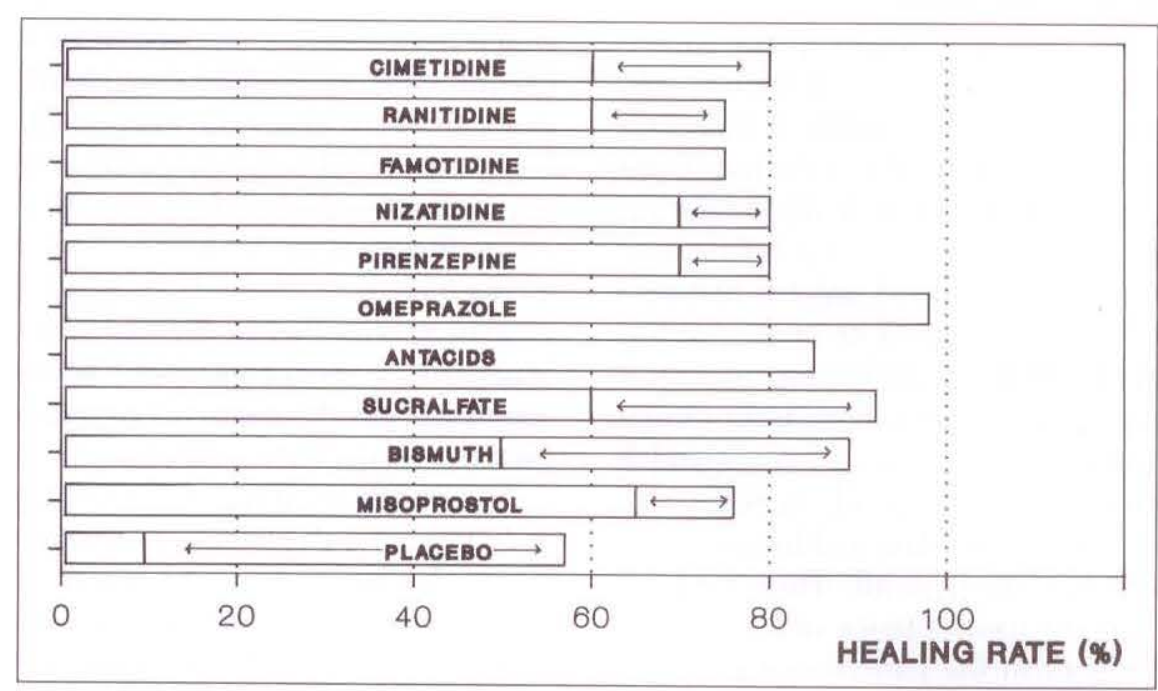

Figure 2) Healing rates of duodenal ulcer with different antiulcer drugs after four weeks of treatment. Arrows show the ranges among multiple studies

misoprostol, which is approved in Canada for the treatment of duodenal ulcer, as maintenance therapy for the prevention of recurrence.

Enprostil is a synthetic analogue of prostaglandin $\mathrm{E}_{2}$ with the same properties as misoprostol. Although not yet approved for the treatment of duodenal ulcer in Canada, enprostil has been shown to be superior to placebo in duodenal ulcer healing, and a dose of 35 $\mu \mathrm{g}$ bid is as effective as cimetidine 400 $\mathrm{mg}$ bid (157). However, after four weeks of treatment, ranitidine $150 \mathrm{mg}$ bid produced a healing rate of $93 \%$, versus $46 \%$ with enprostil $35 \mu \mathrm{g}$ bid; ranitidine was statistically superior (164). Side effects and contraindications are the same as with misoprostol (164).

Nicholson et al (165) reviewed 49 trials of treatment of duodenal ulcer with cytoprotective drugs or $\mathrm{H}_{2}$ receptor antagonists. The relapse rate at one year was lower for cytoprotective drugs. As Figure 2 shows, the healing rates in patients with duodenal ulcer are comparable for all drugs except omeprazole.

\section{COMBINATION THERAPY}

Theoretically, using two antiulcer drugs with different mechanisms of action should result in a synergistic effect and a better healing rate than using a single drug. Work reported thus far, however, has not substantiated this hypothesis. One study compared cimetidine $300 \mathrm{mg}$ qid, sucralfate $1 \mathrm{~g}$ qid a combination of both and found no statistically significant difference among the three groups at two, four and eight weeks of treatment, although at two weeks there was a trend in favour of the combination (166).

In another study, randomly assigning patients whose ulcers had not healed after eight weeks of treatment with cimetidine 800 to $1000 \mathrm{mg} /$ day or ranitidine $300 \mathrm{mg} /$ day to receive cimetidine $800 \mathrm{mg} /$ day or cimetidine $800 \mathrm{mg}$ plus pirenzepine $100 \mathrm{mg} /$ day for six weeks, produced a healing rate of $70 \%$ for both groups (167). Investigations of combined therapy have involved small patient samples, so further studies with larger samples are necessary before any generalizations for or against combined therapy can confidently be made.

\section{REFRACTORY DUODENAL ULCER}

Bardhan (168) has defined a refractory duodenal ulcer as one that fails to heal after treatment with cimetidine $1 \mathrm{~g}$ daily for three months. He found a $7 \%$ failure in healing of duodenal ulcers after continuous treatment for three months. In a study of 66 patients with refractory duodenal ulcers, $42 \%$ did not heal after an average of 9.4 months of treatment, despite increment to 2 or 3 $\mathrm{g}$ of cimetidine daily. Nine underwent surgery - five of these had poor results. Patients with refractory ulcers were younger than 40 years and had longer histories, frequent episodes of bleeding, a family history of peptic ulcer, previous treatment with cimetidine, ulcers of medium or large size, and moderate or severe duodenitis compared with patients who responded to cimetidine treatment (168).

The cause of refractoriness is unknown. Noncompliance, genuine resistance (168) and excessive vagal drive (169) have been proposed as explana. tions of the phenomenon. A pathophysiological failure of $\mathrm{H}_{2}$ blockers to suppress acid secretion, especially at night, has been implicated (170). Measurements of intragastric acidity indicated that acid inhibition was lower from midnight to midday and over $24 \mathrm{~h}$ in 10 patients whose ulcers did not heal after three months of treatment with famotidine $40 \mathrm{mg}$ or ranitidine $300 \mathrm{mg}$ at bedtime than in controls (171). In this situation, omeprazole may be the answer. However, the finding by Deakin and Williams (172) that some patients' ulcers did not heal after six weeks of treatment with cimetidine 400 mg twice a day produced overnight achlorhydria, serves to reinforce the multifactorial nature of duodenal ulcer etiology. Thus, when 25 patients whose duodenal ulcers did not heal after four weeks of treatment with a standard dose of cimetidine were randomized to receive colloidal bismuth subcitrate one tablet qid or cimetidine $400 \mathrm{mg}$ qid for four weeks, after which patients whose ulcers did not heal in either treatment were crossed over, the cumulative heal. ing rate was $85 \%$ for colloidal bismuth subcitrate and $40 \%$ for cimetidine (173). Similarly, after patients whose duodenal ulcers had not healed after 10 weeks of treatment with cimetidine or ranitidine were randomized to receive misoprostol $200 \mu \mathrm{g}$ qid or placebo for four weeks, $42 \%$ of those receiving misoprostol and $17 \%$ of those receiving placebo had their ulcers heal (174).

In 1990, very few patients have truly refractory duodenal ulcers, so the need for surgery is minimal in uncomplicated duodenal ulcer disease. With frequent recurrence, however, a maintenance program is required, and in this situation a case can be made for highly selec. 
tive vagotomy to reduce the acid load permanently and thus reduce the risk of recurrent duodenal ulceration, particularly if the patient is a young adult who might otherwise face years of drug therapy. Also, the lesson to be learned is: if a patient does not respond to one

ACKNOWLEDGEMENTS: The authors are grateful to $\mathrm{Mr}$ Peter King for his editorial assistance.

\section{REFERENCES}

1. Lam S-K, Sircus W. Studies on duodenal ulcer. I. The clinical evidence for the existence of two populations. QJ Med 1975;44:369-87.

2. Rotter JI, Rimoin DL. Peptic ulcer disease - A heterogenous group of disorders? Gastroenterology 1977;73:604-7

3. Harrison AR, Elashoff JD, Grossman MI. Peptic ulcer disease. In: Smoking and Health: A Report of the Surgeon General. (DHEW Publication no. PHS 7950066.) Washington: United States Department of Health, Education, and Welfare, 1979:9.1-9.21.

4. Doll R, Jones AF, Pygott F. Effect of smoking on the production and mainenance of gastric and duodenal ulcers. Lancet 1958;i:657-62.

5. Shepherd AMM, Stewart WK, Wormsley KG. Peptic ulceration in chronic renal failure. Lancer 1973;i:1357-9.

6. Bennet JR. Smoking and the gastrointestinal tract. Gut 1972;13:658-65.

7. Massarrat S, Eisenmann A. Factors affecting the healing rate of duodenal and pyloric ulcers with low-dose antacid treatment. Gut 1981;22:97-102

8. Tenenbaum J. Non-steroidal anti-inflammatory drugs (NSAIDs) cause gastrointestinal intolerance and major bleeding - or do they? Clin Invest Med 1987;10:246-50.

9. Misiewicz JJ. Histamine $\mathrm{H}_{2}$-receptor antagonist in short and long-term treatment of duodenal ulcer. In: Holtermuller KH, Malagelada JR, eds. Advances in Ulcer Disease. Amsterdam: Excerpta Medica, 1980.

10. Lam SK, Lai CL, Lee NW, et al. Effective healing of duodenal ulcer with single night time dose of oxmetidine - A double-blind controlled study. Gastroenterology 1983;84:1221. (Abst)

11. Walsh JH, Lam SK. Physiology and pathology of gastrin. Clin class of antiulcer drug, increase the dose (in the absence of side effects) or prescribe a drug with a different mechanism of action.

In conclusion, there are many efficacious drugs for the treatment of peptic ulcer disease. The choice of the drug(s)

Gastroenterol 1980;9:567-91.

12. Samloff IM, Taggart RT. Pepsinogens, pepsins, and peptic ulcer. Clin Invest Med 1987;10:215-21.

13. Pearson J, Allen A, Venables C. Gastric mucus: Isolation and polymeric structure of the undegraded glycoprotein: Its breakdown by pepsin. Gastroenterology 1980;78:709-15.

14. McQueen S, Hutton D, Allen A, Garner A. Gastric and duodenal surface mucus gel thickness in rat: Effects of prostaglandins and damaging agents. Am J Physiol 1983;245:G388-93.

15. Heatley NG. Mucosubstance as a barrier to diffusion. Gastroenterology 1959;37:313-7.

16. Pfeiffer CJ. Experimental analysis of hydrogen ion diffusion in gastrointestinal mucus glycoprotein Am J Physiol 1981;240:676-82.

17. Allen A. Structure and function of gastrointestinal mucus. In: Johnson LR, Christensen J, Grossman MI, Jacobson ED, Schultz SG, eds. Physiology of the Gastrointestinai Tract. New York: Raven Press, 1981:617-39.

18. Turnberg LA. Gastric mucus, bicarbonate and $\mathrm{pH}$ gradients in mucosal protection. Clin lnvest Med 1987;10:178-80.

19. Isenberg JI, Hogan DL, Selling JA, Koss MA. Duodenal bicarbonate secretion in normal subjects and duodenal ulcer patients. Dig Dis Sci 1985;30:381. (Abst)

20. Quigley EMM, Turnberg LA. Neutral micro-climate lines human gastroduodenal mucosa in vivo. Gut 1985;26:1117. (Abst)

21. Williams SE, Turnberg LA. Demonstration of a $\mathrm{pH}$ gradient across mucus adherent to rabbit gastric mucosa: Evidence for a 'mucus-bicarbonate' barrier. Gut 1981;22:94-6.

22. Lichtenberger LM. Membranes and barriers: With a focus on the gastric mucosal barrier. Clin Invest Med 1987;10:181-8

23. Kivilaakso E, Silen W. Pathogenesis of experimental gastric mucosal injury. N Engl J Med 1979;301:364-9.

24. Cheung LY, Ashley SW. Gastric blood flow and mucosal defense mechanisms. is based on individual preferences and other medical history of the patient, particularly smoking, concomitant medications, age and cost of the medication, which can vary up to three to fourfold for the treatment of duodenal ulcers.

Clin Invest Med. 1987;10:201-8

25. Malagelada J-R, Larach JR. Gastric emptying in duodenal ulcer. Scand ] Gastroenterol 1980;63:115-30.

26. Borgström S, Arborelius M Jr. Duodenal motility pattern in duodenal ulcer disease. Scand J Gastroenterol 1978;13:349-52.

27. Monto GL, Ashworth WD, Malecki $M$, Thompson AB, Englert E.

Duodenal contraction wave patterns in patients with and without ulcer. Am J Gastroenterol 1976;65:52-6.

28. Pihan G, Gallagher GT, Szabo S Biliary and pancreatic secretions influence experimental duodenal ulcer without affecting gastric secretion in the rat. Dig Dis Sci 1986;30:240-6.

29. Hazell SL, Lee A, Brady L, Hennessy W. Campylobacter pyloridis and gastritis: Association with intercellular spaces and adaptation to an environment of mucus as important factors in colonization of the gastric epithelium. J Infect Dis 1986;153:658-63.

30. Bartlett JG. Campylobacter pylori: Fact or fancy? Gastroenterology 1988;94:229-32. (Edit)

31. Slomiany BL, Bilski J, Murty VLN, et al. Campylobacter pyloridis degrades mucin and undermines gastric mucosal integrity. Gastroenterology 1987;92:1645. (Abst)

32. Coughlan JG, Gilligan D, Humphries $\mathrm{H}$, et al. Campylobacter pylori and recurrence of duodenal ulcers - A 12-month follow-up study. Lancet 1987;ii:1109-11

33. Coughlan G, Gilligan D, Humphries $\mathrm{H}$, et al. Campylobacter pyloridis and relapse of duodenal ulcers. Gastroenterology 1987;92:1355. (Abst)

34. Eberhardt R, Kasper G, Dettmer A, Höchter W, Hagena D. Effect of oral bismuthsubsalicylate on Campylobacter pyloridis and on duodenal ulcer. Gastroenterology 1987;92:1379. (Abst)

35. Sturdevant RAL, Walsh JH. Duodenal ulcer. In: Sleisenger MH, Fordtran JS, eds. Gastrointestinal Disease Pathophysiology, Diagnosis, Management, 2nd edn. Philadelphia: WB Saunders Company, 1978:840-60

36. Salena BJ, Hunt RH. The limitations of current therapy in peptic ulcer disease. Clin Invest Med 1987;10:171-7. 
37. Thompson ABR, Mahachai $V$. Pharmacological management of patients with peptic ulcer disease: Prospects for the late 1980's. Clin Invest Med 1987;10:152-70.

38. Lam S-K, Koo J. Accurate prediction of duodenal-ulcer healing rate by discriminant analysis. Gastroenterology 1983;85:403-12.

39. Piper DW, McIntosh JH, Ariotti DE, Fenton BH, MacLennan R. Analgesic ingestion and chronic peptic ulcer. Gastroenterology 1981;80:427-32.

40. Soll AH, Grossman MI. Cellular mechanisms in acid secretion. Annu Rev Med 1978;29:495-507.

41. De Gara CJ, Jones DB, Hunt RH. A physiological basis for the rational therapy of peptic ulcer. Mod Concepts Gastroenterol 1986;1:1-32.

42. Saccomani G, Helander HF, Crago S, Chang HH, Dailey DW, Sachs C. Characterization of gastric mucosal membranes. X. Immunological studies of gastric $\left(\mathrm{H}^{+} \mathrm{K}^{+}\right)$ATPase. J Cell Biol 1979;83:271-83.

43. Sachs $G$, Chang H, Rabon E, Shackmann R, Sarau HM, Saccomani G.

Metabolic and membrane aspects of gastric $\mathrm{H}^{+}$transport. Gastroenterology 1977;73:931-40.

44. Branski D, Sharon P, Karmeli F, Rachmilewicz D. Effect of cimetidine on human gastric and duodenal prostanoid synthesis. Scand J Gastroenterol 1984;19:457-60.

45. Wollin A. Regulation of gastric acid secretion at the cellular level. Clin Invest Med 1987;10:209-14.

46. Debas HT, Mulholland MW. New horizons in the pharmacologic management of peptic ulceration. Am J Surg 1986;151:422-30.

47. Weir DG. Peptic ulceration. Br Med J 1988;296:195-200.

48. Thompson ABR, Mahachai V. Medical management of uncomplicated peptic ulcer disease. In: Berk JE, ed. Bockus Gastroenterology, 4th edn. Philadelphia: WB Saunders, 1985:1116-54.

49. Navert $\mathrm{H}$, Archambault AP, Cleator IGM, et al. The efficacy of two therapeutic regimens of cimetidine in the treatment of duodenal ulcer disease - A Canadian multicenter trial. Annu Rev Coll Phys Surg Canada 1983;16:332. (Abst)

50. Kildebo S, Aronsen O, Bernersen B, et al. Cimetidine, $800 \mathrm{mg}$ at night, in the treatment of duodenal ulcers. Scand J Gastroenterol 1985;20:1147-50.

51. Korman MG, Shaw RG, Hansky J, Schmidt GT, Stern AI. Influence of smoking on healing rate of duodenal ulcer in response to cimetidine or high-dose antacid. Gastroenterology 1981;80:1451-3.

52. Gugler T, Rohner H-G, Kratochvil P, Brandstätter G, Schmitz H. Effect of smoking on duodenal ulcer healing with cimetidine and oxmetidine. Gut 1982;23:866-71

53. Bardhan KD. Long term management of duodenal ulcer. A physician's view. In: Baron JH, ed. Cimetidine in the 80s. Edinburgh: Churchill-Livingstone, 1981.

54. Walan A, Porro GB, Hentschel E. Maintenance cimetidine for up to three years. Lancet 1985;i:115-6.

55. Sontag S, Graham DY, Belsito A, et al. Cimetidine, cigarette smoking, and recurrence of duodenal ulcer. $\mathrm{N}$ Engl J Med 1984;311:689-93.

56. Thomas JM, Misiewicz G. Histamine $\mathrm{H}_{2}$ receptor antagonists in the shortand long-term treatment of duodenal ulcer. Clin Gastroenterol 1984;13:501-41.

57. Delitala G, Stubbs WA, Wass JAH, Jones A, William S, Besser GM. Effects of the $\mathrm{H}_{2}$ receptor antagonist cimetidine on pituitary hormones in man. Clin Endocrinol 1979;11:161-7.

58. Jensen RT, Collen MJ, Pandol SJ, et al. Cimetidine-induced impotence and breast changes in patients with gastric hypersecretory states. N Engl ] Med 1983;308:883-7.

59. McMillen MA, Ambis D, Siegel JH. Cimetidine and mental confusion. N Engl J Med 1978;298:284-5.

60. McGuigan JE. A consideration of the adverse effects of cimetidine. Gastroenterology 1981;80:181-92.

61. Smith IR, Cleverley MT, Ganellin CR, Metters KM. Binding of $\left[{ }^{3} \mathrm{H}\right]$ cimetidine to rat brain tissue. Agents Actions 1980;10:422-6.

62. Lakoski JM, Aghajanian GK, Gallager DW. Interaction of histamine $\mathrm{H}_{2}$ receptor antagonists with GABA and benzodiazepine binding sites in the CNS. Eur J Pharmacol 1983;88:241-5.

63. Peden NR, Saunders JHB, Wormsley KG. Inhibition of pentagastrin-stimulated and nocturnal gastrin secretion by ranitidine: A new $\mathrm{H}_{2}$ receptor antagonist. Lancet 1979;i:690-2.

64. Rendic S, Alebic-Kolbah T, Kajfez F, Ruf $\mathrm{H}-\mathrm{H}$. Interaction of ranitidine with liver microsomes. Xenobiotica 1982;12:9-17.

65. Pearce P, Funder JW. Histamine $\mathrm{H}_{2}$ receptor antagonist: Radioreceptor assay for antiandrogenic side effects. Clin Exp Pharmacol Physiol 1980;7:442. (Abst)

66. Nelis GF, van de Meene JGC. Comparative effect of cimetidine and ranitidine on prolactin secretion. Postgrad Med J 1980;56:478-80.
67. Colin-Jones DG. Medical treatment of peptic ulcer. In: Misiewicz JJ, Pounder RE, Venables CW, eds. Diseases of the Gut and Pancreas. Oxford: Blackwell Scientific Publications, 1987:288-315.

68. Peden NR, Boyd EJS, Saunders JHB, Wormsley KG. Ranitidine in the treatment of duodenal ulceration. Scand J Gastroenterol 1981;16:325-9

69. MacKay C, Mohammed R, Lee FI, Fielding JD, Holmes GKT, Hine K. The effect of ranitidine, a new histamine $\mathrm{H}_{2}$ receptor antagonist on the healing rate of duodenal ulceration. Gastroenterology 1981;80:1219. (Abst)

70. Dobrilla G, Granata F, Feleler M, Piazzi L, Castelli G. A single nocturnal dose of ranitidirie for the short-term treatment of duodenal ulcer: Interim results of an Italian multicentre study In: Misiewicz JJ, Wood JR, eds. Ranitidine: Therapeutic Advances. Amsterdam: Excerpta Medica, 1984:154-67.

71. Boyd EJS, Wilson JA, Wormsley KG Safety of ranitidine maintenance treatment of duodenal ulcer. Scand J Gastroenterol 1984;19:394-400.

72. Korman MG, Hansky J, Merrett AC, Schmidt GT. Ranitidine in duodenal ulcer: Healing rate and effect of smoking. Gastroenterology 1981;80:1197. (Abst)

73. Boyd EJ, Wilson JA, Wormsley KG. Review of ulcer treatment: Role of ranitidine. J Clin Gastroenterol 1983;5(Suppl 1):133-41.

74. Gough KR, Korman MG, Bardhan $\mathrm{KD}$, et al. Ranitidine and cimetidine in prevention of duodenal ulcer relapse: A double-blind, randomised, multicentre, comparative trial. Lancet 1984;ii:659-62.

75. Silvis SE. Final report on the United States multicenter trial comparing ranitidine to cimetidine as maintenance therapy following healing of duodenal ulcer. J Clin Gastroenterol 1985;7:482-7.

76. Gledhill T, Howard OM, Buck M, Paul A, Hunt RH. Single nocturnal dose of an $\mathrm{H}_{2}$ receptor antagonist for the treatment of duodenal ulcer. Gut 1983;24:904-8.

77. Archambault AP, Pare P, Bailey RJ, et al. Omeprazole ( $20 \mathrm{mg}$ daily) versus cimetidine (1200 mg daily) in duodenal ulcer healing and pain relief. Gastroenterology 1988;94:1130-4.

78. Müller P, Dammann HG, Schmidt-Gayk H, Lichtwald K, Staiger C, Simon B. Famotidine (MK-208): Duration of action, 24-hour intragastric acidity, antipyrine kinetics and basal hormone levels in man. Gastroenterology 1984;86:1190. (Abst) 79. Smith JL, Camal MA, Chremos AN, 
Graham DY. Famotidine, a new $\mathrm{H}_{2}$ receptor antagonist: Effect on parietal, nonparietal, and pepsin secretion in man. Dig Dis Sci 1985;30:308-12.

80. Ryan R. Clinical pharmacology of famotidine: Summary of data from the United States. Ital J Gastroenterol 1984;16:171-4.

81. Ohe K, Miyoshi A, Yachi A, et al. Famotidine clinical pharmacology: Japanese studies. Ital J Gastroenterol 1984:16:1250.

82. Staiger C, Korodnay B, Devries ]. Comparative effects of famotidine and cimetidine on antipyrine kinetics in healthy volunteers. $\mathrm{Br} \mathrm{J}$ Clin Pharmacol 1984;18:105-6.

83. Barbara L, Corinaldesi R, Bianchi Porro G, et al. Famotidine in the management of duodenal ulcer: Experience in Italy. Digestion 1985;32(Suppl 1):24-31.

84. Simon B, Dammann HG, Jakob G, et al. Famotidine versus ranitidine for the short-term treatment of duodenal ulcer. Digestion 1985;32(Suppl 1):32-7.

85. Bianchi Porro G. Famotidine in the treatment of gastric and duodenal ulceration: Overview of clinical experience. Digestion 1985;32 (Suppl 1):62-9.

86. Morton DM. Pharmacology and toxicology of nizatidine. Scand J Gastroenterol 1987;136:1-8.

87. Callaghan JT, Bergstrom RF, Rubin A, et al. A pharmacokinetic profile of nizatidine in man. Scand J Gastroenterol 1987;136:9-17

88. Klotz U. Lack of effect of nizatidine on drug metabolism. Scand ] Gastroenterol 1987;136:18-23.

89. Van Thiel DH, Gavaler JS, Heyl A, Susen B. An evaluation of the antiandrogen effects associated with $\mathrm{H}_{2}$ antagonist therapy. Scand J Gastroenterol 1987;136:24-8.

90. Kovacs TOG, Van Deventer GM, Maxwell V, Sytnik B, Walsh JH. The effect of an oral evening dose of nizatidine on nocturnal and peptonestimulated gastric acid and gastrin secretion. Scand J Gastroenterol 1987;136:41-6.

91. Dyck WP, Cloud ML, Offen WW, Matsumoto C, Chernish SM. Treatment of duodenal ulceration in the United States. Scand J

Gastroenterol 1987;136:47-55.

92. Simon B, Cremer M, Dammann HG, et al. $300 \mathrm{mg}$ nizatidine at night versus $300 \mathrm{mg}$ ranitidine at night in patients with duodenal ulcer: A multicentre trial in Europe. Scand J Gastroenterol 1987;136:61-70.

93. Cerulli MA, Cloud ML, Offen WW, Chernish SM, Matsumoto C. Nizatidine as maintenance therapy of duodenal ulcer disease in remission.
Scand J Gastroenterol 1987;136:79-83.

94. Hentschel E, Schütze K, Reichel W, et al. Nizatidine versus ranitidine in the prevention of duodenal ulcer relapse: Six-month interim results of a European multicentre study. Scand J Gastroenterol 1987;136:84-8.

95. Carmine AA, Brogden RN.

Pirenzepine: $A$ review of its pharmacodynamic and pharmacokinetic properties and therapeutic efficacy in peptic ulcer disease and other allied diseases. Drugs 1985;30:85-126.

96. Hirschowitz Bl, Fong J, Molina E. Effects of pirenzepine and atropine on vagal and cholinergic gastric secretion and gastrin release and on heart rate in the dog. J Pharmacol Exp Ther 1983;225:263-8

97. Bianchi Porro C, Prada A, Parente F, Sangaletti $O$, Lazzaroni $M$. The effect of pirenzepine on meal-stimulated gastric acid secretion, gastric release and gastric emptying. Scand J Gastroenterol 1982;72:159-62.

98. Dammann HG, Simon B, Müller P, Krüger $\mathrm{HJ}$. Hemmung der nächtlichen Nüchternsekretion durch Pirenzepin. Arzneimittelforschung 1982;32:309-10

99. Jaup BH. Studies on the mode of action of pirenzepine in man with special reference to its anticholinergic muscarinic properties. Scand J Gastroenterol 1981;68:1-26.

100. Texter EC Jr, Reilly PA. The efficacy and selectivity of pirenzepine: Review and commentary. Scand ] Gastroenterol 1982;72:237-46.

101. Giorgi-Conciato M, Daniotti S, Ferrari PA, et al. Efficacy and safety of pirenzepine in peptic ulcer and in non ulcerous gastroduodenal diseases: A multicentre controlled clinical trial. Scand J Gastroenterol 1982;81:1-42.

102. Visconti GP, Spotti D, Grasso GA, Papetti G, Marini U. Long-term trial of pirenzepine, cimetidine and placebo in the management of duodenal ulcer. Curr Ther Res 1983;34:853-6.

103. Dal Monte PR, Bianchi Porro G, Petrillo M, Giuliani-Piccari G, D'Imperio N, Daniotti S. Long-term treatment of duodenal ulcer with pirenzepine: A double-blind, placebo-controlled trial. Scand J Gastroenterol 1982;72:225-8.

104. Walan A. Antacids and anticholinergics in the treatment of duodenal ulcer. Clin Gastroenterol 1984;13:473-99.

105. Barbara L, Belsasso E, Bianchi Porro G, et al. Pirenzepine in duodenal ulcer: A multicentre double-blind controlled clinical trial: Second of two parts. Scand J Gastroenterol 1979;57:17-9.

106. Fellenius E, Berglindh T, Sachs C, et al. Substituted benzimidazoles inhibit gastric acid secretion by blocking $\left(\mathrm{H}^{+}+\mathrm{K}^{+}\right)$ATPase. Nature 1981;290:159-61.

107. Londong W, Londong V, Cederberg C, Steffen H. Dose-response study of omeprazole on meal-stimulated gastric acid secretion and gastrin release. Gastroenterology 1983;85:1373-8.

108. Borg KO, Olbe L. Omeprazole: Survey of preclinical data. Scand J

Gastroenterol 1985;108:1-120.

109. Prichard PJ, Yeomans ND, Mihaly GW, et al. Omeprazole: A study of its inhibition of gastric $\mathrm{pH}$ and oral pharmacokinetics after morning or evening dosage. Gastroenterology 1985;88:64-9.

110. Prichard PJ, Rubinstein D, Jones DB, et al. Double blind comparative study of omeprazole $10 \mathrm{mg}$ and $30 \mathrm{mg}$ daily for healing duodenal ulcers. Br Med J 1985;290:601-3.

111. Sharma BK, Santana IA, Wood EC, et al. Intragastric bacterial activity and nitrosation before, during, and after treatment with omeprazole. Br Med J 1984;289:717-9.

112. Festen HPM, Thijs JC, Lamers CBHW, et al. Effect of oral omeprazole on serum gastrin and serum pepsinogen I levels. Gastroenterology 1984;87:1030-4.

113. Blanchi A, Rotenberg A, Soule JC, et al. Traitement de l'ulcère duodénal en poussée par l'oméprazole: Résultats d'une étude non controlée multicentrique. Gastroenterol Clin Biol 1984;8:943-6.

114. Lauritsen K, Rune SJ, Bytzer P, et al. Effect of omeprazole and cimetidine on duodenal ulcer: A double-blind comparative trial. N Engl J Med 1985:312:958-61.

115. Malagelada J-R, Carlson GL. Antacids and $\mathrm{HCl}$. Scand J Gastroenterol 1982;75:10-2.

116. Lam SK, Lam KC, Lai CL, Yeung CK, Yam LYC, Wong WS. Treatment of duodenal ulcer with antacid and sulpiride: A double-blind controlled study. Gastroenterology 1979;76:315-22.

117. Kumar N, Vij JC, Karol A, Anand BS. Controlled therapeutic trial to determine the optimum dose of antacids in duodenal ulcer. Gut 1984;25:1199-202.

118. Bardhan KD. Are antacids as effective as cimetidine in preventing duodenal ulcer relapse? A multicenter study. Gastroenterology 1986;90:1336. (Abst)

119. Barnett CC, Richardson CT. In vivo and in vitro evaluation of magnesium-aluminum hydroxide antacid tablets and liquid. Dig Dis Sci 1985;30:1049-52.

120. Ippoliti AF. Antacid therapy for duodenal and gastric ulcer; The 
experience in the United States. Scand J Gastroenterol 1982;75:82-5.

121. Herzog P, Holtermüller K-H. Antacid therapy - Changes in mineral metabolism. Scand J Gastroenterol 1982;75:56-62.

122. Walan A. Metabolic side-effects and interactions. Scand J Gastroenterol 1982;75:63-8.

123. Barreras RF. Acid secretion after calcium carbonate in patients with duodenal ulcer. N Engl J Med 1970;282:1402-5.

124. Fordtran JS. Acid rebound. N Engl J Med 1968;279;900-5.

125. Brogden RN, Heel RC, Speight TM, Avery GS. Sucralfate: A review of its pharmacodynamic properties and therapeutic use in peptic ulcer disease. Drugs 1984;27:194-209.

126. Nagashima R, Yoshida N. Sucralfate, a basic aluminum salt of sucrose sulfate. I. Behaviors in gastroduodenal $\mathrm{pH}$. Arzneimittelforschung 1979;29:1668-76.

127. Nagashima R. Mechanisms of action of sucralfate. J Clin Gastroenterol 1981;3(Suppl 2):17-127.

128. Konturek SJ, Kwiecien N, Obtulowicz W, Kopp B, Olesky J. Double blind controlled study on the effect of sucralfate on gastric prostaglandin formation and microbleeding in normal and aspirin treated man. Gut 1986;27:1450-6.

129. Tytgat GNJ, Hameeteman W, Van Olffen GH. Sucralfate, bismuth compounds, substituted benzimidazoles, trimipramine and pirenzepine in the short and long-term treatment of duodenal ulcer. Clin Gastroenterol 1984;13:543-68.

130. Sherman RA, Hwang ER, Walker JA, Elsinger RP. Reduction in serum phosphorus due to sucralfate. Am J Gastroenterol 1983;78:210-1.

131. Fixa B, Komarkova O. Aluminum sucrose sulphate (sucralfate) in the treatment of peptic ulcer (double blind study). In: Caspary WF, ed. Sucralfate: A New Therapeutic Concept.

Baltimore: Urban and Schwarzenberg, 1981:80-4.

132. Hentschel E, Schütze K, Dufek W. Controlled comparison of sucralfate and cimetidine in duodenal ulcer. Scand J Gastroenterol 1983;83:31-5.

133. Marks IN, Wright JP, Lucke W, Girdwood JH. Relapse rates after initial ulcer healing with sucralfate and cimetidine. Scand J Gastroenterol 1982;17:429-32.

134. Moshal MG, Spitaels J-M, Manion CL. Double-blind placebo-controlled evaluation of one year therapy with sucralfate in healed duodenal ulcer. Scand J Gastroenterol 1983;83:57-60.

135. Classen M, Bethge $H$, Brunner G, et al. Effect of sucralfate on peptic ulcer recurrence: A controlled double-blind multicenter study. Scand J Gastroenterol 1983;83:61-8.

136. Brogden RN, Pinder RM, Sawyer PR, Speight TM, Avery GS. Tri-potassium di-citrato bismuthate; a report on its pharmacological properties and therapeutic efficacy in peptic ulcer. Drugs 1976;12:401-11.

137. Baron JH, Barr J, Batten J, Sidebotham $\mathrm{R}$, Spencer J. Acid, pepsin and mucus secretion in patients with gastric and duodenal ulcer before and after colloidal bismuth subcitrate (De-Nol). Gut 1986;27:486-90.

138. Bekker J, Pinatsis A. Information about De-Nol chewing tablets. J Drug Res 1982;7:1541-5.

139. Lee SP. A potential mechanism of action of colloidal bismuth subcitrate: Diffusion barrier to hydrochloric acid. Scand J Gastroenterol 1982;80:17-21.

140. Wilson TR. The pharmacology of tri-potassium di-citrato bismuthate (TDB). Postgrad Med J 1975;51 (Suppl 5):18-21.

141. Lee FI, Samloff IM, Hardmarn M. Comparison of tri-potassium di-citrato bismuthate tablets with ranitidine in healing and relapse of duodenal ulcer. Lancet 1985;i:1299-302.

142. Martin DF, Hollanders D, May SJ, Ravenscroft MM, Tweedle DEF, Miller JP. Difference in relapse rates of duodenal ulcer after healing with cimetidine or tripotassium dicitrato bismuthate. Lancet 1981;i:7-10.

143. Vantrappen C, Schuurmans $P$, Rutgeerts P, Janssens J. A comparative study of colloidal bismuth subcitrate and cimetidine on the healing and recurrence of duodenal ulcer. Scand J Gastroenterol 1982;80:23-30.

144. Cohen MM. Role of endogenous prostaglandins in gastric secretion and mucosal defense. Clin Invest Med 1987;10:226-31.

145. Tsai BS, Kessler LK, Schoenhard G, et al. E-type prostaglandin binding sites in isolated canine parietal cells: Elucidation with $\left({ }^{3} \mathrm{H}\right)$ misoprostol free acid. Z Gastroenterol 1987;25:201-6.

146. Chen MCY, Amirian DA, Toomey M, Sanders MJ, Soll AH. Prostanoid inhibition of canine parietal cells: Mediation by the inhibitory guanosine triphosphate-binding protein of adenylate cyclase. Gastroenterology 1988;94:1121-9.

147. Garner A, Heylings JR. Stimulation of alkaline secretion in amphibian-isolated gastric mucosa by 16,16-dimethyl $\mathrm{PGE}_{2}$, and $\mathrm{PGF}_{2} \alpha \mathrm{A}$ proposed explanation for some of the cytoprotective actions of prostaglandins. Gastroenterology 1979;76:497-503.
148. Kauffman GL, Grossman MI. Gastric alkaline secretion: Effect of topical and intravenous 16-16 dimethyl prostaglandin $\mathrm{E}_{2}$. Gastroenterology 1979;76:1165. (Abst)

149. Helander HF, Johansson C, Blom H, Uribe A. Trophic actions of $\mathrm{E}_{2}$ prostaglandins in the rat gastrointestinal mucosa: A quantitative morphologic study. Gastroenterology 1985;89:1393-9.

150. Bolton JP, Palmer D, Cohen MM. Stimulation of mucus and nonparietal cell secretion by the $\mathrm{E}_{2}$ prostaglandins. Am J Dig Dis 1978;23:359-64.

151. Leung FW, Robert A, Guth PH. Gastric mucosal blood flow in rats after administration of 16,16-dimethyl prostaglandin $\mathrm{E}_{2}$ at a cytoprotective dose. Gastroenterology 1985;88:1948-53.

152. Ahlquist DA, Dozois RR, Zinsmeister AR, Malagelada J-R. Duodenal prostaglandin synthesis and acid load in health and in duodenal ulcer disease. Gastroenterology 1983;85:522-8.

153. Howden CW, Burget DW, van Eeden A, Hunt RH. Enisoprost: Marked inhibition of histamine-stimulated acid and pepsin secretion in man. Gastroenterology 1986;90:1466. (Abst)

154. Bauer RF. Misoprostol: Preclinical pharmacology. Dig Dis Sci 1985;30:118S-25S.

155. McGuigan JE, Chang Y, Dajani EZ. Effect of misoprostol, an antiulcer prostaglandin, on serum gastrin in patients with duodenal ulcer. Dig Dis Sci 1986;31:120S-5S.

156. Steiner JA. Misoprostol clinical pharmacology: Establishment of activity in man. Dig Dis Sci 1985;30:136S-41S.

157. Hawkey CJ, Walt RP. Prostaglandins for peptic ulcer: A promise unfulfilled. Lancet 1986;ii:1084-7.

158. Schoenhard C, Oppermann J, Kohn FE. Metabolism and pharmacokinetic studies of misoprostol. Dig Dis Sci 1985; 30:126S-8S.

159. Brand DL, Roufail WM, Thompson ABR, Tapper EJ. Misoprostol, a synthetic $P E_{1}$, analog, in the treatment of duodenal ulcers: A multicenter double-blind study. Dig Dis Sci 1985;30:147S-58S.

160. Sontag SJ, Mazure PA, Pontes JF, Beker SC, Dajani EZ. Misoprostol in the treatment of duodenal ulcer: $\mathrm{A}$ multicenter double-blind placebo-controlled study. Dig Dis Sci 1985;30:159S-63S.

161. Bright-Asare P, Sontag SJ, Gould RJ, et al. Efficacy of misoprostol (twice daily dosage) in acute healing of duodenal ulcer: A multicenter double-blind controlled trial. Dig Dis 
Sci 1986;31:63S-7S.

162. Nicholson PA. A multicenter international controlled comparison of two dosage regimes of misoprostol and cimetidine in the treatment of duodenal ulcer in out-patients. Dig Dis Sci 1985;30:171S-7S.

163. Lam SK, Lau WY, Choi TT, et al. Prostaglandin $\mathrm{E}_{1}$ (misoprostol) overcomes the adverse effect of chronic cigarette smoking on duodenal ulcer healing. Dig Dis Sci 1986:31:68S-74S.

164. Bardhan KD, Bose K, Hinchliffe RFC, et al. Enprostil (E) versus ranitidine $(\mathrm{R})$ in duodenal ulcer (DU). Gut 1985;26:1149. (Abst)

165. Nicholson P, Swabb E, Clay G, Soucheck J. Duodenal ulcer relapse following acute healing by misoprostol or $\mathrm{H}_{2}$ antagonist: $\mathrm{A}$ global analysis of 49 trials. In: Symposium on Clinical Developments on Misoprostol: Peptic
Ulcer Disease and NSAID Induced Gastropathy. Chicago: GD Searle and Co, 1987.

166. Van deventer GM, Schneidman D, Walsh JH. Sucralfate and cimetidine as single agents and in combination for treatment of active duodenal ulcers: A double-blind, placebo-controlled trial. Am J Med 1985;79(Suppl 2C):39-44.

167. Bardhan KD, Thompson M, Bose K, et al. Combined anti-muscarinic and $\mathrm{H}_{2}$ receptor blockade in the healing of refractory duodenal ulcer: A double blind study. Gut 1987;28:1505-9.

168. Bardhan KD. Refractory duodenal ulcer. Gut 1984;25:711-7.

169. Gledhill T, Buck M, Hunt RH. Effect of no treatment, cimetidine $1 \mathrm{~g} /$ day, cimetidine $2 \mathrm{~g} /$ day and cimetidine combined with atropine on nocturnal gastric secretion in cimetidine non-responders. Gut 1984;25:1211-6.

170. Bardhan KD, Kapur B, Hinchliffe
RFC. Cimetidine or vagotomy? $\mathrm{Br}]$ Surg 1984;71:402-3. (Lett)

171. Savarino V, Mela GS, Scalabrini P, Celle G. $\mathrm{H}_{2}$-receptor antagonist nonresponders. Lancet 1987;ii:1281. (Lett)

172. Deakin M, Williams JG. $\mathrm{H}_{2}$-receptors antagonist non-responders. Lancet 1988;i:127-8.

173. Lam SK, Lee NW, Koo J, Hui WM, Fok $\mathrm{KH}, \mathrm{Ng} \mathrm{M}$. Randomised crossover trial of tripotassium dicitrato bismuthate versus high dose cimetidine for duodenal ulcers resistant to standard dose of cimetidine. Gut 1984;25:703-6.

174. Gitlin N. The role of misoprostol in the management of peptic ulcer disease. Symposium of Clinical Developments on Misoprostol: Peptic Ulcer Disease and NSAID Induced Gastropathy. Chicago: GD Searle and Co, 1987. 


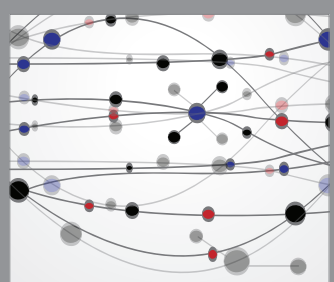

The Scientific World Journal
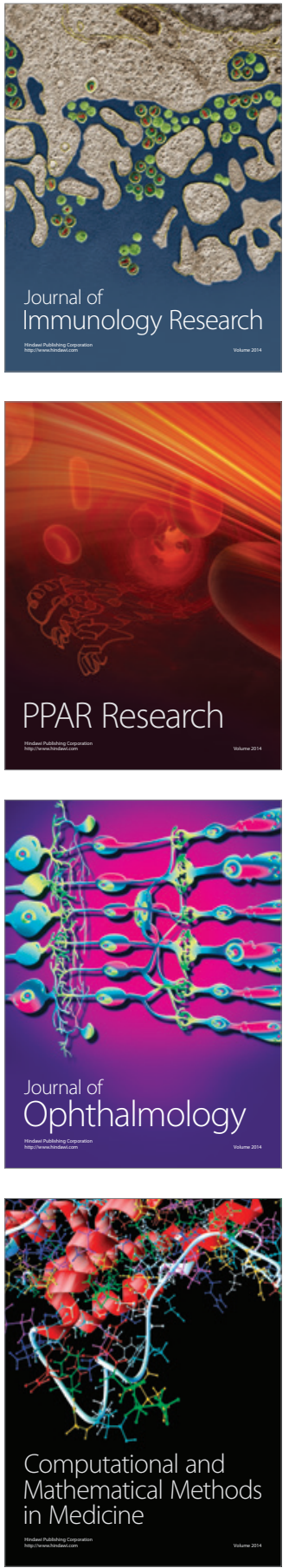

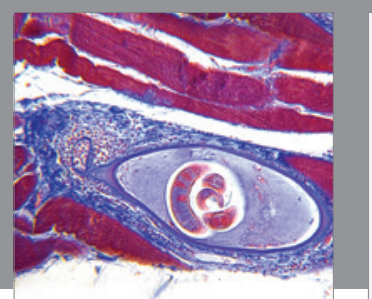

Gastroenterology Research and Practice

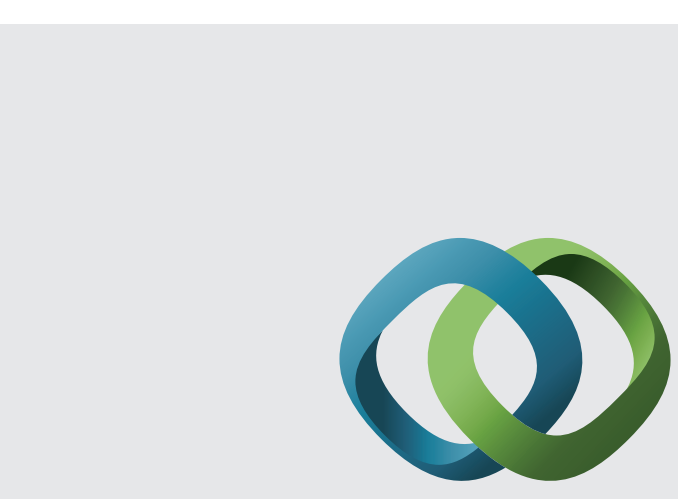

\section{Hindawi}

Submit your manuscripts at

http://www.hindawi.com
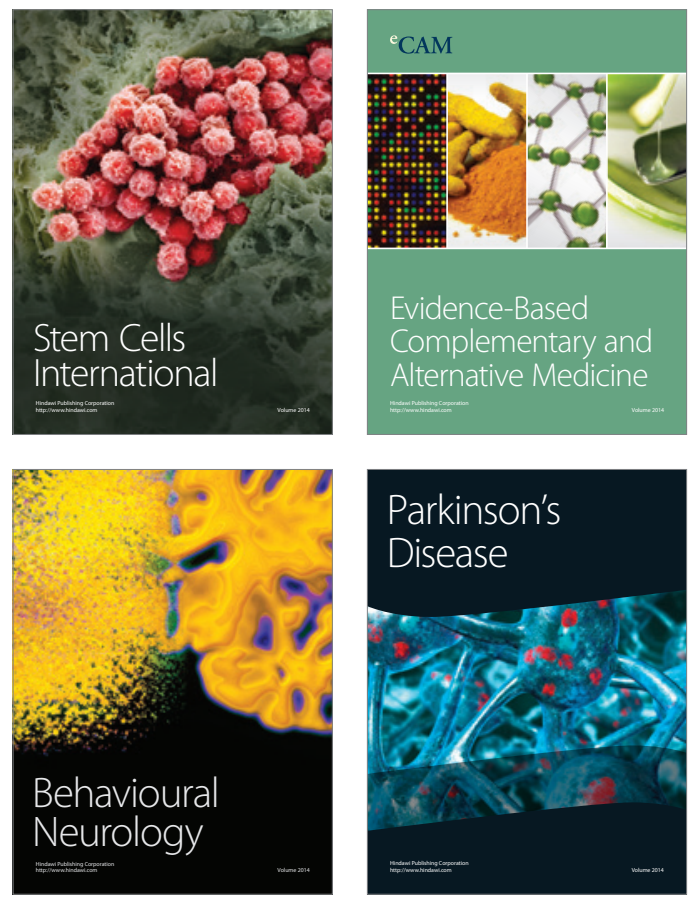
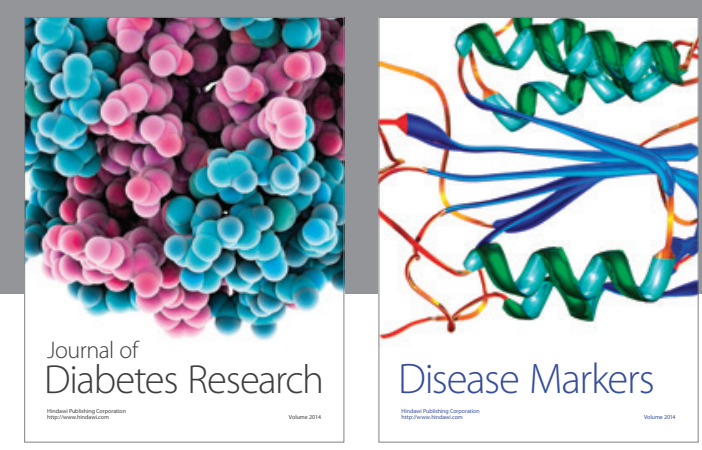

Disease Markers
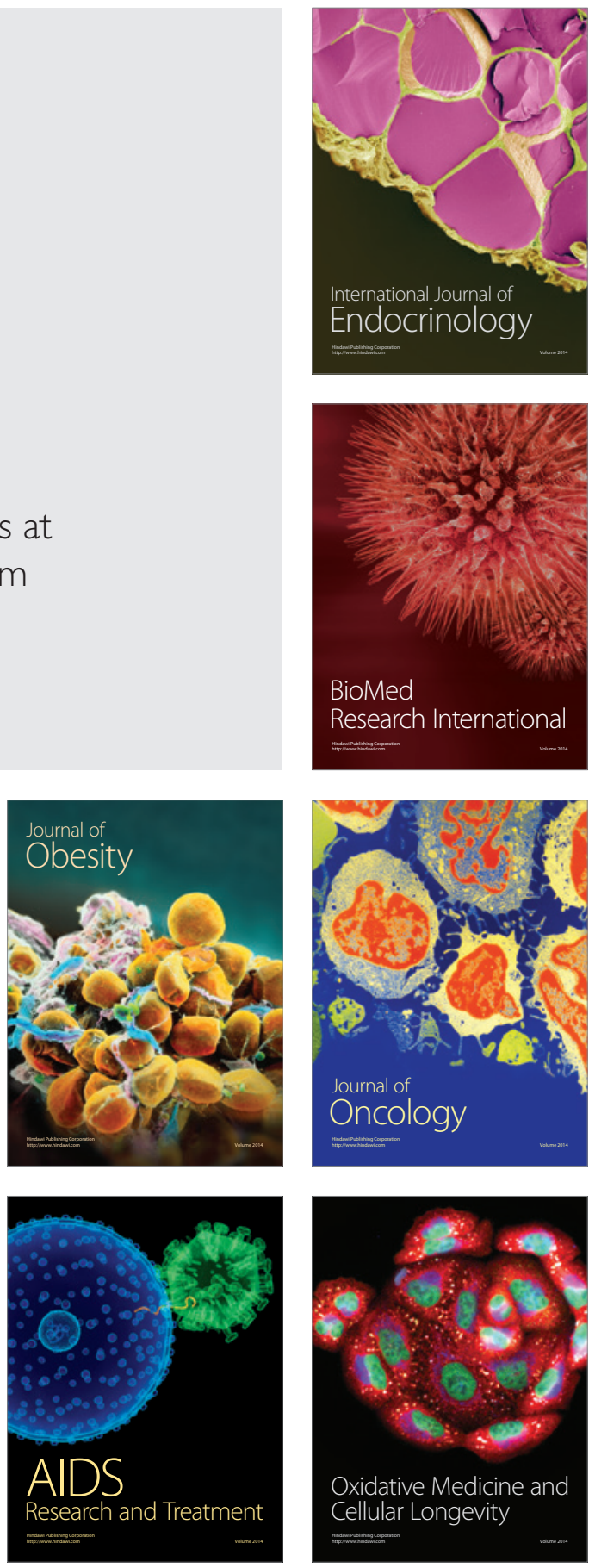